\title{
The Influence of Social Capital and Ownership Structure on Enterprise Value in China's Steel Industry
}

\author{
Kunseng Lao \\ School of Business, Macau University of Science and \\ Technology \\ Macau, China
}

\author{
Xuechun Li \\ School of Business, Macau University of Science and \\ Technology \\ Macau, China
}

\begin{abstract}
The environmental protection industry is an important part of the development of a country's green economy and plays an irreplaceable role in the process of China's socialist modernization. In recent years, environmental protection companies have developed rapidly, gradually subdivided their industries, persisted in innovation, and catched up with the pace of environmental protection companies in developed countries. China's environmental protection industry will continue to encounter new opportunities and challenges. Corporate social capital and ownership structure have become an important driving factor in the creation of corporate value in the new era. This paper takes the environmental protection industry as the starting point, studies the influence of social capital and ownership structure on the corporate value, and provides reference for the management of the enterprise.
\end{abstract}

Keywords-ownership structure; enterprise social capital; enterprise value

\section{INTRODUCTION}

Through the reform of the economic system, it provides a better political environment for the economic development of our country. The all-round reform of the system and policy provides a new level of development for the economic development of our country. At present, our country is changing from extensive economic development mode to resource intensive one. The development of industrial structure has changed dramatically. All walks of life are facing the challenge of optimizing industrial structure. Today's corporate culture has evolved from previous competition and distrust to win-win cooperation in order to maximize profits. With the development of global economy, the voice of green economy is getting higher and higher, and China is no exception. The development of environmental protection industry needs in the composite era. For this reason, the text combines the social capital situation and ownership structure of environmental protection industry in our country, and analyses the value impact of enterprises, so as to provide reference for promoting the healthy development of environmental protection industry in our country.

\section{RESEARCH METHODS}

This paper chooses panel data model, considering two factors: first, by constructing panel data model for empirical analysis, we can get multiple cross-sections in time series, which can reveal the essential characteristics of such sample data and obtain more reasonable results to a certain extent; second, when building panel data model for empirical research, we can. In order to control the unobservable differences of some individuals to a certain extent, the contribution of each explanatory variable to the explanatory variable can be estimated effectively. In order to verify the relationship between social capital and right-of-use structure of related companies in environmental protection industry, a set of econometric models were established with Tobin $\mathrm{Q}$ value as explanatory variable, supplier-related capital, employeerelated capital, managerial ownership and ownership concentration as explanatory variables, and company size and asset-liability ratio as control variables. Model 1:

TobinQit $=\alpha 0+\alpha 1$ APTit $+\alpha 2$ Loyaltyit $+\alpha 3$ Ownit $+\alpha 4$ Manait $+\alpha 5$ SIZEit $+\alpha 6$ LEVit $+\varepsilon$

Among them, alpha 0 is a constant term. Alpha $\mathrm{i}(\mathrm{i}=1 \ldots 5)$ is an exponential coefficient, I represents the sample environmental protection company, T represents the year. E is the residual term, which indicates the difference between the actual observation value and the regression estimate value.

TobinQ: Tobin $Q$ value

APT: Supplier Relational Capital

Loyalty: Employee Relational Capital

Own: Equity Concentration

Mana: Management Equity

SIZE: Enterprise Size

LEV: Asset-liability ratio

\section{EMPIRICAL RESEARCH AND ANALYSIS}

This paper selects 86 environmental protection enterprises in China from 2012 to 2016 as sample data to empirically test the impact of social capital and ownership structure of environmental protection enterprises on enterprise value. In order to ensure the validity of the sample data, the following aspects are considered in the selection of samples: Firstly, the 
selected companies are listed on the main board of Shanghai Stock Exchange and Shenzhen Stock Exchange, excluding B shares, avoiding the possible fluctuations of data; secondly, the data is meaningful and the ST is eliminated. Stocks, and such abnormal data may have an impact on the study; third, in the choice of time, the financial data disclosure is not complete and the changes of financial data are unstable, so the choice of data is more reasonable, and the comparison of selected samples is meaningful.

\section{A. Descriptive statistical analysis}

Empirical research shows that:

TABLE I MODEL 1 DESCRIPTIVE STATISTICS

\begin{tabular}{lllll}
\hline Variable & Min & Max & Mean & S.D \\
\hline TobinQ & 0.045 & 0.529 & 0.290 & 0.212 \\
APT & 0.008 & 0.375 & 0.165 & 0.132 \\
Loyalty & 0.001 & 0.142 & 0.074 & 0.096 \\
Own & 0.053 & 0.400 & 0.110 & 0.130 \\
Mana & 0.000 & 0.624 & 0.219 & 0.132 \\
SIZE & 19.189 & 27.446 & 23.165 & 1.439 \\
LEV & 0.046 & 1.202 & 0.649 & 0.181 \\
\hline
\end{tabular}

From Table 1, we can see that the average value of Tobin $\mathrm{Q}$ is 0.29 , the maximum value is 0.529 , but the minimum value is 0.045 , so we can conclude that the value difference of the industry is large. The minimum value of supplier relationship capital is 0.008 , the maximum value is 0.375 , and the average value is 0.165 , which is not much different from the standard deviation of 0.132 , indicating that the turnover rate of accounts payable of suppliers is generally not high. The average value of employee relationship capital is 0.0074 , and the standard deviation is 0.096. Therefore, the overall employee relationship capital in this industry is not high. Improving social capital through employees is not the main channel of this industry. The average equity concentration is 0.11 , the standard deviation is 0.130 , and Max is 0.400 , which indicates that the overall equity concentration in this industry is moderate. The difference between Min and Max is large, but the average and median are moderate, which shows that the management ownership of environmental protection industry is more reasonable.

\section{B. Relevance analysis}

From Table 2, it is concluded that Tobin $Q$ value is positively correlated with ownership concentration, the correlation coefficient is 0.2683 , passing $10 \%$ significance; Tobin $\mathrm{Q}$ value is positively correlated with management ownership, the correlation coefficient is 0.1546 , passing $10 \%$ significance test; Tobin Q value is negatively correlated with employee social capital, the correlation coefficient is -0.2227 , passing $10 \%$ significance test; Tobin $\mathrm{Q}$ value is positively correlated with supplier relationship capital. Guan, but the correlation is not significant. For control variables, Tobin Q value is positively correlated with company size, the correlation coefficient is 0.1880 , passing the $10 \%$ significance test; Tobin Q value is positively correlated with asset-liability ratio, but the correlation is not significant. According to Hossain and other studies, the correlation coefficient between variables does not exceed 0.75 , which will not affect the multivariate linear regression analysis. Variables are independent, which can exclude the possibility of collinearity and meet the criteria of multivariate regression model.

TABle II MOdel 1 PeARSON COEFFICIENT

\begin{tabular}{|c|c|c|c|c|c|c|c|}
\hline Variable & TobinQ & LEV & SLR & EFR & IFR & $\mathrm{CF}$ & SIZE \\
\hline TobinQ & 1.000 & & & & & & \\
\hline APT & 0.0022 & 1.000 & & & & & \\
\hline Loyalty & $-0.2227 *$ & $0.1300^{*}$ & 1.000 & & & & \\
\hline Own & $0.2683^{*}$ & -0.0135 & $-0.4351 *$ & 1.000 & & & \\
\hline Mana & $0.1546^{*}$ & 0.014 & $-0.4464 *$ & 0.0318 & 1.000 & & \\
\hline SIZE & $0.1880^{*}$ & $-0.1184 *$ & $-0.6978 *$ & $0.1667^{*}$ & $0.4280^{*}$ & 1.000 & \\
\hline LEV & 0.0465 & $-0.1132 *$ & $-0.7420 *$ & $-0.2399 *$ & $0.4640 *$ & $0.6143^{*}$ & 1.000 \\
\hline
\end{tabular}

Note: * Represents a significant level of $10 \%$

\section{Multivariate regression analysis}

Tables 3 and 4 are the regression results of establishing the model of random effect and fixed effect.
TABLE III MODEL 1 RANDOM EFFECT MODEL REGRESSION RESULTS

\begin{tabular}{llll}
\hline Variable & $\alpha$ & $\mathrm{Z}$ & $\mathrm{P}$ \\
\hline $\mathrm{C}$ & $-4.027^{* *}$ & -2.60 & 0.009 \\
APT & $0.255^{* * *}$ & 4.64 & 0.000 \\
Loyalty & $-0.286^{* * *}$ & -2.64 & 0.008 \\
Own & $1.269^{*}$ & 1.82 & 0.069 \\
Mana & -0.082 & -0.82 & 0.415 \\
SIZE & 0.025 & 0.38 & 0.700 \\
LEV & 0.575 & 1.63 & 0.103 \\
R2=0.1508,chi2 & & & \\
$=55.96, \mathrm{P}=0.000$ & & & \\
\hline
\end{tabular}


TABLE IV MODEL 1 FIXED-EFFECT MODEL REGRESSION RESULTS

\begin{tabular}{lccc}
\hline Variable & $\alpha$ & $\mathrm{t}$ & $\mathrm{P}$ \\
\hline $\mathrm{C}$ & $1.703 * *$ & 0.70 & 0.485 \\
APT & $0.261 * * *$ & 4.23 & 0.000 \\
Loyalty & $-0.253 * *$ & -2.08 & 0.039 \\
Own & $6.587 * * *$ & 5.63 & 0.000 \\
Mana & 0.019 & 0.14 & 0.892 \\
SIZE & $-0.229 * *$ & -2.25 & 0.025 \\
LEV & $0.842 *$ & 1.93 & 0.055 \\
R2 $=0.2360, \mathrm{~F}=1$ & & & \\
$4.00, \mathrm{P}=0.0000$ & & & \\
\hline
\end{tabular}

Table 5 is a Likelihood test using mixed-effect model and fixed-effect model.

TABLE V LIKELIHOOD TEST

\begin{tabular}{cccc}
\hline Effects Test & Statistic & d.f. & Prob. \\
\hline Cross-section F & 4.42 & $-81,272$ & 0.000 \\
$\begin{array}{c}\text { Cross-section } \\
\text { Chi.Sq }\end{array}$ & 57.766 & 81 & 0.000
\end{tabular}

According to Table 5, the $\mathrm{P}$ values of $\mathrm{F}$ statistics and LR tests are less than 0.05 , so we reject the original hypothesis that individual effects are not significant and choose the fixed effect model.

Table 6 is a Hausman test of 2 model using random effect model and fixed effect model.

TABLE VI HAUSMAN TEST RESULTS

\begin{tabular}{cc}
\hline & model 2 \\
\hline Chi-Sq.Statistic & 46.09 \\
Chi-Sq.d.f. & 7 \\
Prob & 0.000 \\
\hline
\end{tabular}

From Table6, the Chi-Sq.Statistic value of model 2 is 46.09 , and the concomitant probability is 0.000 , respectively. It shows that the fixed effect model should be selected for regression estimation of model 2 . The model analysis is as follows:

\section{1) Goodness of fit}

The adjusted $\mathrm{R}$ in the model is 0.2360 , which shows that $23.60 \%$ of the changes in Tobin $Q$ value of the dependent variable enterprise value evaluation index can be explained by various variables. The overall test $F$ statistic is 14.00 and the adjoint probability is 0 .

\section{2) Analysis of regression results}

In the regression relationship, the exponential supplier relationship capital and ownership concentration pass the $1 \%$ significance test and have a positive correlation; the employee relationship capital passes the $5 \%$ significance test and has a negative correlation; the managerial ownership does not pass the 5\% significance level test, indicating that the significance of this variable is not very strong, but has a positive correlation. The size of the controlling variable company has passed the $5 \%$ significance test, and has a negative correlation; the asset-liability ratio has passed the $10 \%$ significance test, and has a positive correlation.

\section{CONCLUSION}

This paper takes 86 listed environmental protection industries as samples, and the sample interval is from 2012 to 2016. This paper takes Tobin $Q$ value as dependent variable, two measures of social capital (supplier relationship capital, employee relationship capital) and two measures of ownership structure (managerial ownership, ownership concentration) as explanatory variables, and enterprise size (SIZE) and assetliability ratio (LEV) as control variables. Through descriptive analysis, correlation analysis, unit root test, multiple regression analysis and other methods to test the topic, and finally adopt a fixed effect model to carry out a regression analysis of enterprise value. Taking the environmental protection industry as the breakthrough point, this paper studies how the enterprise value and ownership structure affect the enterprise value. After a thorough understanding of the existing theoretical achievements of social capital, ownership structure and corporate value, this paper explores the topic by combining theoretical and empirical research methods.

\section{REFERENCES}

[1] Ameer, R., Ramli, F., Zakaria, H. (2010). A new perspective on board composition and firm performance in an emerging market. Corporate Governance, 10(5), 647-661

[2] Anirudh Krishna (2002).Active Social Capital Tracing the Roots of Development and Democracy[M].Columbia University Press:27.

[3] Baker, W. E. (2000). Networking smart: how to build relationships for personal and organizational success. Academy of Management Executive, 8(2), 85-86.

[4] Brown, B., \& Butler, J. E. (1995). Competitors as allies: a study of entrepreneurial networks in the u.s. wine industry. Journal of Small Business Management, 33(3), 57-66.

[5] Burt,R. S. (1995). Structural holes : the social structure of competition Harvard University Press.

[6] Chen,J.(2001).Ownership structure as corporate governance mechanism: evidence from Chinese listed companies. Economics of Planning, 34(12), 53-72.

[7] Dore, R. (1983). Goodwill and the spirit of market capitalism. British Journal of Sociology, 34(4), 459-482.

[8] Durlauf, S.N, \& Fafchamps. (2003). Empirical studies of social capital a critical survey. Journal of Chemical Physics, 92(6), 3359-3376.

[9] Hanifan, L. J. (1916). The rural school community center. Annals of the American Academy of Political \& Social Science, 67(1), 130-138

[10] Putnam, R. D. (1995). Bowling alone: america's declining social capital. Journal of Democracy, 6(1), 65-78. 